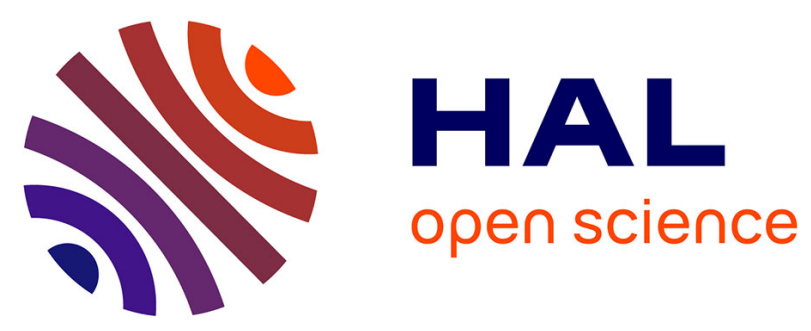

\title{
Determination of Free and Total Sulfites in Wine using an Automatic Flow Injection Analysis System with Voltammetric Detection
}

Luís Moreira Gonçalves, João Grosso Pacheco, Paulo Jorge Magalhães, José António Rodrigues, Aquiles Araújo Barros

\section{To cite this version:}

Luís Moreira Gonçalves, João Grosso Pacheco, Paulo Jorge Magalhães, José António Rodrigues, Aquiles Araújo Barros. Determination of Free and Total Sulfites in Wine using an Automatic Flow Injection Analysis System with Voltammetric Detection. Food Additives and Contaminants, 2009, 27 (02), pp.175-180. 10.1080/19440040903261547 . hal-00572617

\section{HAL Id: hal-00572617 https://hal.science/hal-00572617}

Submitted on 2 Mar 2011

HAL is a multi-disciplinary open access archive for the deposit and dissemination of scientific research documents, whether they are published or not. The documents may come from teaching and research institutions in France or abroad, or from public or private research centers.
L'archive ouverte pluridisciplinaire HAL, est destinée au dépôt et à la diffusion de documents scientifiques de niveau recherche, publiés ou non, émanant des établissements d'enseignement et de recherche français ou étrangers, des laboratoires publics ou privés. 


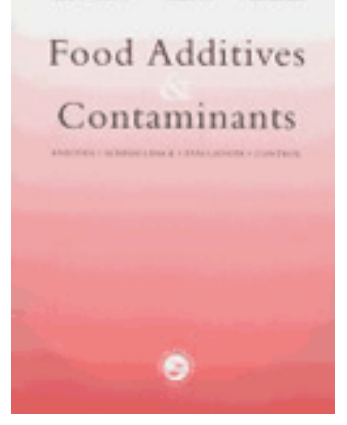

\section{Determination of Free and Total Sulfites in Wine using an Automatic Flow Injection Analysis System with Voltammetric Detection}

\begin{tabular}{|r|l|}
\hline Journal: & Food Additives and Contaminants \\
\hline Manuscript ID: & TFAC-2009-154.R1 \\
\hline Manuscript Type: & Original Research Paper \\
\hline Duthor: & 14-Aug-2009 \\
\hline Complete List of Authors: & $\begin{array}{l}\text { Gonçalves, Luís; Faculdade de Ciências da Universidade do Porto, } \\
\text { Departamento de Química } \\
\text { Pacheco, João; Faculdade de Ciências da Universidade do Porto, } \\
\text { Departamento de Química } \\
\text { Magalhães, Paulo; Faculdade de Ciências da Universidade do Porto, } \\
\text { Departamento de Química } \\
\text { Rodrigues, José; Faculdade de Ciências da Universidade do Porto, } \\
\text { Departamento de Química } \\
\text { Barros, Aquiles; Faculdade de Ciências da Universidade do Porto, } \\
\text { Departamento de Química }\end{array}$ \\
\hline Fothod Types: & Wine \\
\hline Additives/Contaminants: & Sulfite \\
\hline Fochniques: & Analysis - Polagraphy, Method validation, Stripping Voltammetry \\
\hline
\end{tabular}

\section{SCHOLARONE ${ }^{\text {M }}$ \\ Manuscripts}




\section{Determination of Free and Total Sulfites in Wine using an Automatic Flow Injection Analysis System with Voltammetric Detection}

Luís Moreira Gonçalves,* João Grosso Pacheco, Paulo Jorge Magalhães, José António

Rodrigues and Aquiles Araújo Barros

REQUIMTE - Departamento de Química da Faculdade de Ciências da Universidade do Porto (FCUP),

Porto, Portugal

*luis.goncalves@fc.up.pt

An automated Flow Injection Analysis (FIA) system based on a initial analyte separation by gas-diffusion and subsequent determination by square-wave voltammetry (SWV) in a flow cell is proposed for the determination of total and free content of sulphur dioxide $\left(\mathrm{SO}_{2}\right)$ in wine. The proposed method was compared with two iodometric methodologies (the Ripper method and a simplified method commonly used by the wine industry). The developed method shown repeatability (RSD lower than 6\%) and linearity (between 10 to $\left.250 \mathrm{mg} \cdot \mathrm{L}^{-1}\right)$ as well as suitable LOD. $\left(3 \mathrm{mg} \cdot \mathrm{L}^{-1}\right)$ and LOQ $\left(9 \mathrm{mg} \cdot \mathrm{L}^{-1}\right)$. A major advantage of this system is that $\mathrm{SO}_{2}$ is directly detected by flow $\mathrm{SWV}$.

Keywords: Wine; Sulphur dioxide; Sulfites; Gas-diffusion; Square-wave voltammetry; Flow injection analysis (FIA); Food analysis; Food additives; Analytical chemistry

\section{Introduction}

$\mathrm{SO}_{2}$ and its source compounds, such as sulfite salts, are widely used as preservatives in the food industry. They are added to foods and beverages, in order to prevent undesirable microbial growth, discoloration and oxidation processes, consequently improving the quality and final appearance of the products. In wine, sulphur dioxide is usually found either free (as $\mathrm{HSO}_{3}{ }^{-}, \mathrm{SO}_{3}{ }^{2-}$ and $\mathrm{SO}_{2}$, depending on the sample's $\mathrm{pH}$ ), or bound to carbonyl and unsaturated compounds and/or phenol derivatives (Barbe et al. 2000).

The relevance of $\mathrm{SO}_{2}$ determination in food analysis is widely established; in the particular case of wine, its control is essential not only because at high levels it produces an unpleasant aroma and taste but also because of health hazards especially for hypersensitive people (Decnop-Weever et al. 1997). $\mathrm{SO}_{2}$ levels should be checked before bottling in order to be adjusted for a suitable aging and at the end-product to comply with existing legal limits (Segundo et al. 2001). In the EU the maximum level of total $\mathrm{SO}_{2}$ permitted is 160 
$\mathrm{mg} \cdot \mathrm{L}^{-1}$ for red wines and $210 \mathrm{mg} \cdot \mathrm{L}^{-1}$ for white and rosé wines (EC 1999).

There are many alternative methods proposed for the determination of free and total $\mathrm{SO}_{2}$ in wine. Nevertheless, voltammetric methodologies appear to be the most accurate ones (Bruno et al. 1979, Cardwell et al. 1991, Sarudi et al. 1998). The EU recommended method (EC 1990) is based on the classical Monier-Williams procedure (Monier-Williams 1927) which involves a sample distillation under an inert atmosphere (e.g. nitrogen). Then the analyte is collected in a hydrogen peroxide solution producing sulphuric acid, which can be determined by titration using sodium hydroxide. In spite of its general applicability, the long time required for the analysis precludes a more extensive use of the Monier-Williams method, especially in routine analysis. The Ripper method is a direct iodometric titration which is prone to interferences from iodine-reactive compounds and has been strongly criticized (Maquieira et al. 1993). In general, iodometric methods (rather common simplifications of the Ripper method) are preferred by the wine industry (Azevedo et al. 1999). For the determination of free $\mathrm{SO}_{2}$, the sample is acidified and is titrated with a standard iodine solution, using starch as the indicator. For the determination of total $\mathrm{SO}_{2}$, the sample is previously treated with sodium hydroxide to release the bound $\mathrm{SO}_{2}$. The results should be interpreted with caution because of the solutions' poor stability, the possible occurrence of parallel reactions and additional difficulties associated with the end point observation, especially in the case of the red wines (Azevedo et al. 1999).

During the last years FIA methods have been developed (Dvořák et al. 2006, Oliveira et al. 2009, Ruiz-Capillas et al. 2009). To overcome the problems caused by the colored complex matrix and interferences, some authors proposed manifolds where it is possible to separate the analyte from the wine, by means of gas-diffusion (Araújo et al. 2005, Chinvongamorn et al. 2008, Silva et al. 1998), microdistillation (Maquieira et al. 1993), pervaporation (Mataix et al. 1998) or by using a gas generating and purging device (Zhi et al. 1995), followed by a wide variety of detection methods (Isaac et al. 2006).

The aim of the present work was the development and validation of a rapid and reliable procedure for identification and determination of total and free $\mathrm{SO}_{2}$ in wine samples based on an automatic flow voltammetric system. The direct voltammetric determination of $\mathrm{SO}_{2}$ in wine is difficult because of matrix interference. To develop an on-line analytical method, a separation step has to be employed. Gas-diffusion was used as the separation technique. In this technique there are two distinct chambers separated by a gas permeable hydrophobic membrane. The volatile or semi-volatile analytes are released from the donor chamber, go through the membrane and are collected in the upper chamber where a proper acceptor solution takes them to the instrumental detection. Detection was performed in a patented flow voltammetric cell (Figure 1) that has several advantages, being the most important one the possibility of using high frequency square-waves in flow without oxygen interference 
(Barros et al. 1999).

\section{Materials and methods}

\section{Instrumentation}

Voltammetric measurements (parameters are described in Table 1) were performed with a Metrohm 663 VA Voltammetric Stand (Herisau, Switzerland) equipped with a hanging mercury drop electrode with glassy carbon auxiliary electrode and reference $\mathrm{AgCl} / \mathrm{Ag}(3 \mathrm{M}$ $\mathrm{KCl}$ ) electrode. The system was connected to an Autolab PGSTAT 10 Voltammetric System (Eco Chemie, Utrecht, The Netherlands). All measurements were made at room temperature.

The voltammetric flow cell was manufactured in our laboratory and has been described previously (Barros et al. 2001, 2002, Rodrigues et al. 2001, Rodrigues et al. 2002).

A home-made Perspex gas-diffusion module was used with PTFE membranes, $5.0 \mu \mathrm{m}$ pore size and $47 \mathrm{~mm}$ diameter, from Pall Corporation (Ann Arbor, U.S.A.).

The FIA system is depicted in Figure 2: it includes several three way solenoid valves, a peristaltic pump and PTFE tubing. The sample flow reacts on-line with an acid solution, in the "Y" connection in order to turn all sulfites into $\mathrm{SO}_{2}$; then it goes through a thermostated coil that has the function of pre-heating the donor flow before entering the gas-diffusion module; the $\mathrm{SO}_{2}$ passes through the hydrophobic membrane and is received by the acceptor flow (acetate buffer) that takes it to be instrumentally detected.

The FIA system was incorporated in a prototype (Figure 3). This equipment works automatically with its own purposely designed control software. A GPES 4.9 Software project was developed for automatic voltammetric data acquisition, data saving, and signal processing. It was possible to interconnect both software using a signal trigger transmission.

\section{Chemicals and wine samples}

All reagents used were of p.a. grade and were used without further purification. Ultrapure water from a Millipore Simplicity 185 water purification system (Millipore, Billerica, U.S.A.) was used. The supporting electrolyte (acceptor solution) consisted of acetate buffer pH $4.0\left(0.1 \mathrm{~mol} \cdot \mathrm{L}^{-1}\right)$, sodium acetate was purchased from Merck (Darmstadt, Germany). The buffer's $\mathrm{pH}$ was adjusted with hydrochloric acid, $6 \mathrm{~mol} \cdot \mathrm{L}^{-1}$, from Prolabo (Fontenaysous-Bois, France). $\mathrm{Na}_{2} \mathrm{SO}_{3}$ (Sigma, St. Louis, U.S.A.) was used as a source of $\mathrm{SO}_{2}$. Ethanol was also purchased from Merck.

Some of the wine samples were bought in regular supermarkets in Porto while others were kindly supplied by the Instituto dos Vinhos do Douro e Porto (IVDP).

\section{Sample preparation}


For the determination of free $\mathrm{SO}_{2}$ no sample preparation was required. For the determination of total $\mathrm{SO}_{2}$ an alkaline pre-treatment was essential to destroy the adducts ( $\mathrm{SO}_{2}$ bounded to several aldehydes and ketones) formed in wine (Sarudi et al. 1998). For that purpose $10 \mathrm{~g}$ of sodium hydroxide were added per liter of sample. The sample was homogenized and left to rest for about $20 \mathrm{~min}$.

\section{Results and discussion}

\section{On-line acidification}

The wine sample must be acidified prior to gas diffusion in order to turn all sulfites into $\mathrm{SO}_{2}$, and the $\mathrm{pH}$ must be very low $\left(\mathrm{pk}_{\mathrm{a} 1}=1.77\right.$ and $\left.\mathrm{pk}_{\mathrm{a} 2}=7.22\right)$. On-line acidification with sulfuric acid was achieved using a "Y" shaped connection that helped mixing together the sample flow with the acid flow.

The acid concentration was optimized, knowing that it should be as low as possible to save chemical resources and to prevent the equipment's corrosion but still strong enough to accomplish its objective. After several experiments (Figure 4) concentration chosen was 1 $\mathrm{mol} \cdot \mathrm{L}^{-1}$.

\section{Voltammetric analysis of $\mathrm{SO}_{2}$}

Research on the electrochemical reduction of $\mathrm{SO}_{2}$ in aqueous solution with dropping mercury electrode has reported two waves in acidic medium and no waves in neutral or slightly alkaline media. There has been much disagreement in the interpretation of polarographic reduction of aqueous sulphur dioxide at pH 4 (Streeter et al. 2005). A oneelectron reduction of $\mathrm{HSO}_{3}{ }^{-}$has been suggested (1) (Reynolds et al. 1986) along with the possibility that $\mathrm{HSO}_{3}{ }^{-}$becomes $\mathrm{SO}_{2}$ at the drop's surface, and it is this species reduced in the electrode (2) (Tolmachev et al. 1999).

$$
\begin{aligned}
& \mathrm{HSO}_{3}^{-}+\mathrm{H}^{+}+\mathrm{e}^{-} \rightarrow \mathrm{SO}_{2}^{-}+\mathrm{H}_{2} \mathrm{O} \\
& \mathrm{SO}_{2}+\mathrm{e}^{-} \rightarrow \mathrm{SO}_{2}^{-}
\end{aligned}
$$

Due to matrix effect, standard additions were used to quantify the level of $\mathrm{SO}_{2}$ in the different wine samples (Figure 5). Since the linearity was quite good for routine analysis one single addition was enough.

Two separate determinations must be done for each wine, one for the free sulphur content and another for the total, the difference lays on previous sample treatment with sodium hydroxide for the second case.

\section{Study of interferences}

The level of ethanol in wine varies to a large degree and consequently the influence of 
ethanol concentration was studied. With that purpose, two $\mathrm{SO}_{2}$ calibrations curves (10 to $\left.100 \mathrm{mg} \cdot \mathrm{L}^{-1}\right)$ were compared: one in water and the other one in ethanol $10 \%(\mathrm{v} / \mathrm{v})$, replicating ethanol concentration in wine. As can be perceived in Table 2, ethanol showed no influence in the analysis.

Carbon dioxide is normally found in wine in the concentration range of 1 to $2 \mathrm{~g} \cdot \mathrm{L}^{-1}$ due to the fermentation process (Santos et al. 2006). Previous studies showed that this compound does not interfere in the analytical procedures that make use of gas-diffusion (Santos et al. 2006, Segundo et al. 2001).

\section{Method comparison}

The determination of sulfite concentrations in the different wine samples by the developed flow procedure was compared with the reference "Ripper" method and its simplified version generally used in the wine industry (Figure 6).

The "Ripper" method was performed according to the Portuguese regulation (IPQ 1987) based in a procedure from the Organisation Internationale de la Vigne et du Vin (OIV 2007).

The wine industry normally uses a simple iodometric methodology for routine analysis: instead of the four titrations in the "Ripper" method (one for the free $\mathrm{SO}_{2}$, two for the total $\mathrm{SO}_{2}$ and one for the interferences) only two are carried out (one for the free and another one for the total $\mathrm{SO}_{2}$ ). The methodology consists on iodometric titrations of an acidified wine sample. For the free $\mathrm{SO}_{2}$ determination, $5 \mathrm{~mL}$ of $1: 4 \mathrm{H}_{2} \mathrm{SO}_{4}$ are added immediately before the titration. To determine the total $\mathrm{SO}_{2}$ content, $25 \mathrm{~mL}$ of $1 \mathrm{~mol} \cdot \mathrm{L}^{-1} \mathrm{NaOH}$ are added 15 minutes prior to analysis, in order to perform alkaline hydrolysis, and then $10 \mathrm{~mL}$ of 1:4 $\mathrm{H}_{2} \mathrm{SO}_{4}$ just before the titration.

\section{Method performance characteristics}

Method performance was established by plotting a calibration curve with eight different standards, from 10 to $250 \mathrm{mg} \cdot \mathrm{L}^{-1}$, with six repeated measurements of each point $(\mathrm{n}=6)$ (Table 3). LOD and LOQ (Eurachem 1998) were adequate to wine analysis, though they can be easily decreased with a slight time-consuming change in the procedure. The buffer solution can be stopped and isolated at the upper chamber by this way allowing an incremented quantity of $\mathrm{SO}_{2}$ passage to the upper chamber and consequently an increase in the analytical signal, i.e. the LOD can be lowered by increasing the time needed for each analysis (Figure 7). This makes it possible to analyze matrices with low sulfite content such as beer, juices and other food products. In the present configuration the prototype is able to analyze 15 samples per hour.

\section{Conclusions}


In this paper a new automatic FIA system for the determination of $\mathrm{SO}_{2}$ in wine is described and evaluated. The developed system shows several advantages when compared to other analytical methodologies: voltammetry directly measures $\mathrm{SO}_{2}$ which means a more accurate result; it is especially advantageous with red wines when compared to all the iodometric procedures; it is very versatile, i.e. it can be used with other matrices like beer or juices among others. This analytical procedure was characterized by a good precision, an ample linear application range, an adequate limit of detection and quantification which can be easily lowered if necessary. Good agreement was observed between the proposed new methodology and the one currently used in wine quality control laboratories.

\section{Acknowledgments}

The authors thank the IVDP, particularly Eng. Natália Ribeiro and Eng. Maria José Mirão, for gently supplying us with wine samples and helping us understand the wine industry needs. The authors also wish to thank the European Regional Development Fund (ERDF), the Portuguese Programa Operacional Ciência Tecnologia Inovação (POCTI) and the Portuguese Programa Operacional da Economia (POE) for all the financial support given to project "BEERVOLT" (POCI 2010 - IDEIA, project no. 13-02-03-FDR-01252).

L.M.G. (SFRH/BD/36791/2007), P.J.M. (SFRH/BD/27834/2006) and J.G.P. (SFRH/BD/30279/2006) wish to acknowledge Portuguese Fundação para a Ciência e a Tecnologia (FCT) for their PhD studentships.

\section{References}

Araújo C, Carvalho J, Mota D, Araújo C, Coelho N. 2005. Determination of sulphite and acetic acid in foods by gas permeation flow injection analysis. Food Chem. 92: 765-770.

Azevedo C, Araki K, Toma H, Angnes L. 1999. Determination of sulfur dioxide in wines by gas-diffusion flow injection analysis utilizing modified electrodes with electrostatically assembled films of tetraruthenated porphyrin. Anal Chim Acta. 387: 175-180.

Barbe J, Revel G, Joyeux A, Lonvaud-Funel A, Bertrand A. 2000. Role of carbonyl compounds in $\mathrm{SO}_{2}$ binding phenomena in musts and wines from botrytized grapes. J. Agric. Food Chem. 48: 3413-3419.

Barros A, Rodrigues J, Almeida P, Guido L, Rodrigues P. 2001. Processo para a determinação voltamétrica, célula voltamétrica e dispositivo para determinação em fluxo. Port. Patent 102608.

Barros A, Rodrigues J, Almeida P, Guido L, Rodrigues P. 2002. Process and cell for voltammetric measurement. Eur. Patent 1258725.

Barros A, Rodrigues J, Almeida P, Rodrigues P, Fogg A. 1999. Voltammetry of compounds confined at the hanging mercury drop electrode surface. Anal Chim Acta. 385: 315-323.

Bruno P, Caselli M, Fano A, Traini A. 1979. Fast and simple polarographic method for the determination of free and total sulphur dioxide in wines and other common beverages. Analyst. 104: 1083-1087. 
209 Cardwell T, Cattrall R, Chen G, Scollary G, Hamilton I. 1991. Determination of free sulphur dioxide in 210 red wine by alternating current voltammetry. Analyst. 116: 253-256.

211 Chinvongamorn C, Pinwattana K, Praphairaksit N, Imato T, Chailapakul O. 2008. Amperometric 212 determination of sulfite by gas diffusion-sequential injection with boron-doped diamond electrode. 213 Sensors. 8: 1846-1857.

214 Decnop-Weever L, Kraak J. 1997. Determination of sulphite in wines by gas-diffusion flow injection 215 analysis utilizing spectrophotometric pH-detection. Anal Chim Acta. 337: 125-131.

216 Dvořák J, Dostálek P, Štěrba K, Čejka P, Kellner V, Čulík J, Beinrohr E. 2006. Determination of total 217 sulphur dioxide in beer samples by flow-through chronopotentiometry. J Inst Brew. 112: 308-313.

218 European Union Council. 1990. Methods for the analysis of wines. Off J Eur Commun. L272

219 European Union Council. 1999. Common organisation of the market in wine. Off J Eur Commun. L179 and related topics.

Instituto Português de Qualidade. 1987. Alcoholic and spirituous beverages. Free, combined and total sulphur dioxide content determination. Portuguese Norm 2220

Isaac A, Davis J, Livingstone C, Wain A, Compton R. 2006. Electroanalytical methods for the determination of sulfite in food and beverages. Trends Anal Chem. 25: 589-598.

Maquieira A, Casamayor F, Puchades R, Sagrado S. 1993. Determination of total and free sulphur dioxide in wine with a continuous-flow microdistillation system. Anal Chim Acta. 283: 401-407.

Mataix E, Castro M. 1998. Determination of total and free sulfur dioxide in wine by pervaporation-flow injection. Analyst. 123: 1547-1549.

Moinier-Williams G. 1927. Ministry of Health. The determination of sulphur dioxide in foods. Analyst. 52: 343-344.

Organisation Internationale de la Vigne et du Vin. 2007. Compendium of international methods of wine and must analysis. MA-E-AS323-304-DIOSOU

Oliveira S, Lopes T, Tóth I, Rangel A. 2009. Development of a gas diffusion multicommuted flow injection system for the determination of sulfur dioxide in wines, comparing malachite green and pararosaniline chemistries. J Agric Food Chem. 57: 3415-3422.

Reynolds W, Yuan Y. 1986. Polarographic reduction of aqueous sulfur dioxide. Polyhedron. 5: 14671473.

Rodrigues J, Barros A, Almeida P, Rodrigues P, Fogg A. 2001. Flow injection square wave cathodic stripping voltammetric determination at a hanging mercury drop electrode of rapidly reduced compounds: Determination of diacetyl in wine as 2,3-dimethylquinoxaline. Anal Chim Acta. 449: 119-127.

Rodrigues P, Rodrigues J, Barros A, Lapa R, Lima J, Cruz J, Ferreira A. 2002. Automatic flow system with voltammetric detection for diacetyl monitoring during brewing process. J Agric Food Chem. 50: 3647-3653.

Ruiz-Capillas C, Jiménez-Colmenero F. 2009. Application of flow injection analysis for determining sulphites in food and beverages: A review. Food Chem. 112: 487-493. 
247 Santos J, Korn M. 2006. Exploiting sulphide generation and gas diffusion separation in a flow system for 248 indirect sulphite determination in wines and fruit juices. Microchim Acta. 153: 87-94.

249 Sarudi I, Kelemen J. 1998. Determination of sulphur and total sulphur dioxide in wines by an ICP-AES 250 method. Talanta. 45: 1281-1284.

251 Segundo M, Rangel A. 2001. A gas diffusion sequential injection system for the determination of sulphur 252 dioxide in wines. Anal Chim Acta. 427: 279-286.

253 Silva R, Silva C, Nóbrega J, Neves E. 1998. Flow injection spectrophotometric determination of free and 254 total sulfite in wines based on the induced oxidation of manganese(II). Anal Lett. 31: 2195-2208.

255 Streeter I, Wain A, Davis J, Compton R. 2005. Cathodic reduction of bisulfite and sulfur dioxide in 256 aqueous solutions on copper electrodes: an electrochemical ESR study. J Phys Chem B. 109: 1850025718506.

258 Tolmachev Y, Scherson D. 1999. Electrochemical reduction of bisulfite in mildly acidic buffers: kinetics 259 of sulfur dioxide and bisulfite interconversion. J Phys Chem A. 103: 1572-1578.

260 Zhi Z, Ríos A, Valcárcel M. 1995. Direct determination of free sulfur dioxide in wine and dried apple 261 samples by using a gas generating and purging device coupled to a continuous flow (injection) system. 262 Analyst. 120: 2013-2018.

263 
265 Table 1. SWV parameters.

\begin{tabular}{cccc}
\hline Initial potential & $-400 \mathrm{mV}$ & Final potential & $-850 \mathrm{mV}$ \\
Step potential & $2.5 \mathrm{mV}$ & Amplitude & $25 \mathrm{mV}$ \\
Frequency & $300 \mathrm{~Hz}$ & Drop size & $0.024 \mathrm{~mm}^{3}$
\end{tabular}

266 
267

268 Table 2. Evaluation of the possible interference of ethanol.

\begin{tabular}{ccccc} 
& \multicolumn{2}{c}{ water } & \multicolumn{2}{c}{ ethanol 10\% $(\mathbf{v} / \mathbf{v})$} \\
& $\mathbf{y}=\boldsymbol{m} \mathbf{x}+\boldsymbol{b}$ & $\mathbf{r}^{2}$ & $\mathbf{y}=\boldsymbol{m} \mathbf{x}+\boldsymbol{b}$ & $\mathbf{r}^{2}$ \\
Day 1 & $\mathrm{y}=4.7 \mathrm{x}-7$ & 0.995 & $\mathrm{y}=4.6 \mathrm{x}-16$ & 0.995 \\
Day 2 & $\mathrm{y}=4.6 \mathrm{x}+8$ & 0.998 & $\mathrm{y}=4.5 \mathrm{x}-5$ & 0.999 \\
\hline
\end{tabular}

269 
270

271 Table 3. Method performance characteristics, $\mathrm{I}=\mathrm{f}\left(\left[\mathrm{SO}_{2}\right]\right)$.

\begin{tabular}{ccccc}
\hline Linear dynamic range & $\mathbf{R S D}(\mathbf{n}=\mathbf{6})$ & $\mathbf{r}^{2}$ & LOD & LOQ \\
10 to $250 \mathrm{mg} \cdot \mathrm{L}^{-1}$ & $6 \%$ & 0.9999 & $2.7 \mathrm{mg} \cdot \mathrm{L}^{-1}$ & $9.2 \mathrm{mg} \cdot \mathrm{L}^{-1}$ \\
\hline
\end{tabular}

272 
273

274 Figure 1. Voltammetric flow cell (Barros et al. 2001, 2002).

275

276 Figure 2. Flow system scheme. A - acceptor circuit; B - donor circuit; solid lines - permanent

277 pathway; dashed lines - load step pathway ( 2 min.); dotted lines - injecting step pathway (2

278 min.); PP - peristaltic pump (all with flow rates of $1 \mathrm{~mL} \cdot \mathrm{min}^{-1}$ ); $\mathrm{V}$ - three-way solenoid valve;

$279 \mathrm{H}$ - heating element (both working at $90^{\circ} \mathrm{C}$ ).

280

281

282

283

284

285

286

287

288

289

290

291

292

293

294

295

296

Figure 3. FIA system prototype. V - three-way solenoid valves; PP - peristaltic pump; $\mathrm{H}$ heating elements; GDM - gas-diffusion module.

Figure 4. Signal variation with the sulphuric acid concentration. The sample used in this assay contained a high sulfite level and had endured an alkaline pre-treatment, i.e. reproducing the determination of the total $\mathrm{SO}_{2}$ content.

Figure 5. Voltammograms obtained in the analysis of several standard solutions of $\mathrm{SO}_{2}$. Inset: the calibration curve plotted with the voltammograms' peak height.

Figure 6. Method comparison for the determination of free and total sulphites, three replicates were performed for each method.

Figure 7. Signal variation with the stopped flow time in the upper chamber of the gas-diffusion module. Results were acquired with a standard $20 \mathrm{mg} \cdot \mathrm{L}^{-1} \mathrm{SO}_{2}$ solution. 


1
2
3
4
5
6
7
8
9
10
11
12
13
14
15
16
17
18
19
20
21
22
23
24
25
26
27
28
29
30
31
32
33
34
35
36
37
38
39
40
41
42
43
44
45
46
47
48
49
50
51
52
53
54
55
56
57
58
60

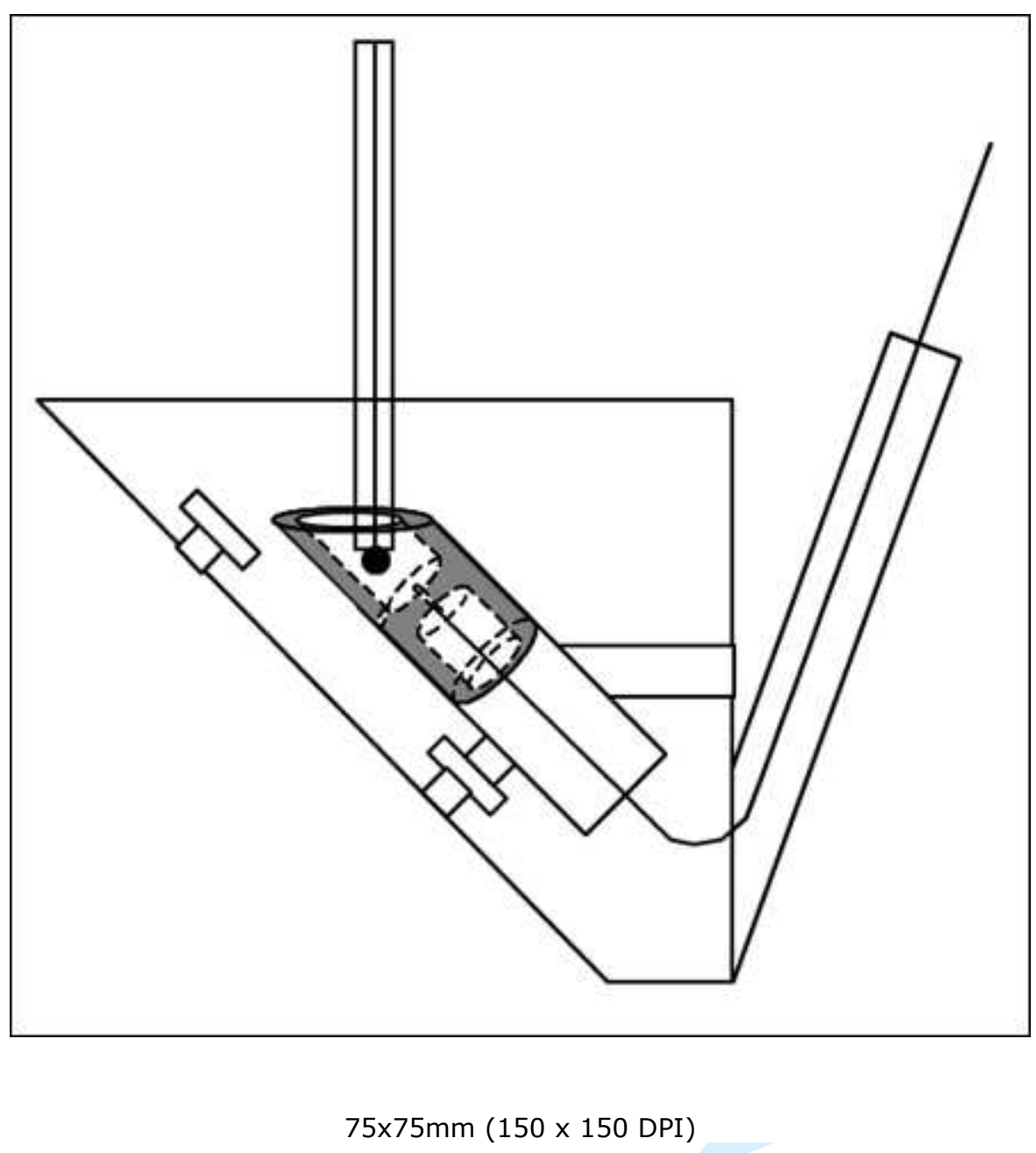

http://mc.manuscriptcentral.com/tfac Email: fac@tandf.co.uk 


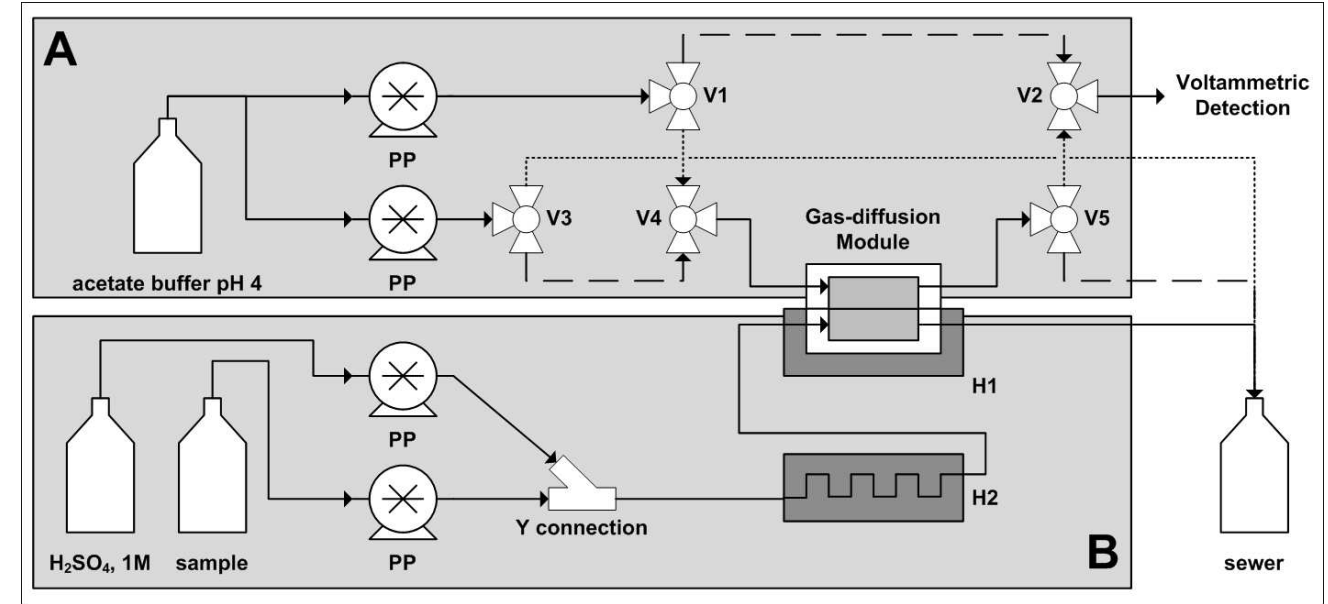

$240 \times 111 \mathrm{~mm}(150 \times 150 \mathrm{DPI})$ 


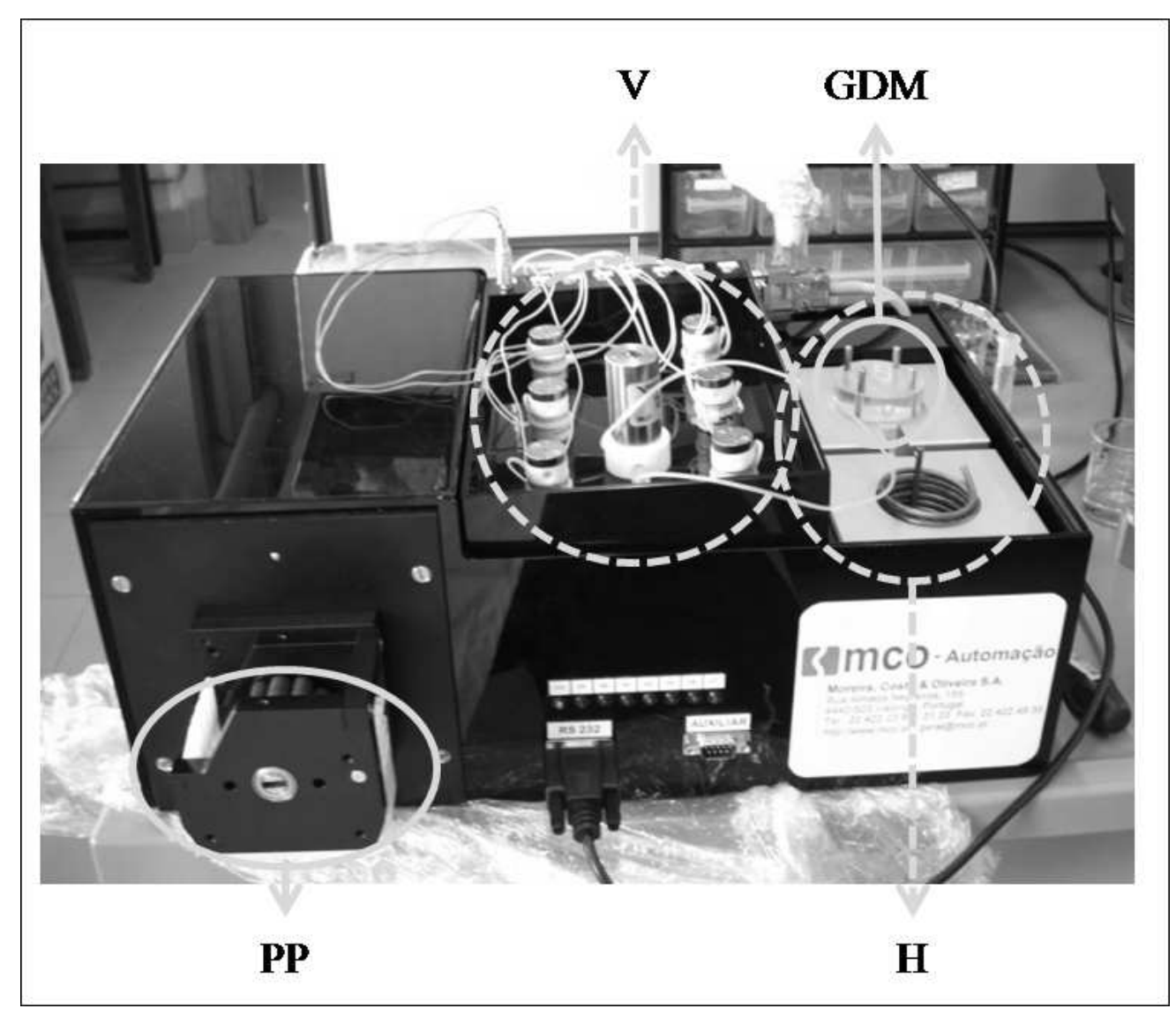

$127 \times 109 \mathrm{~mm}(150 \times 150 \mathrm{DPI})$ 


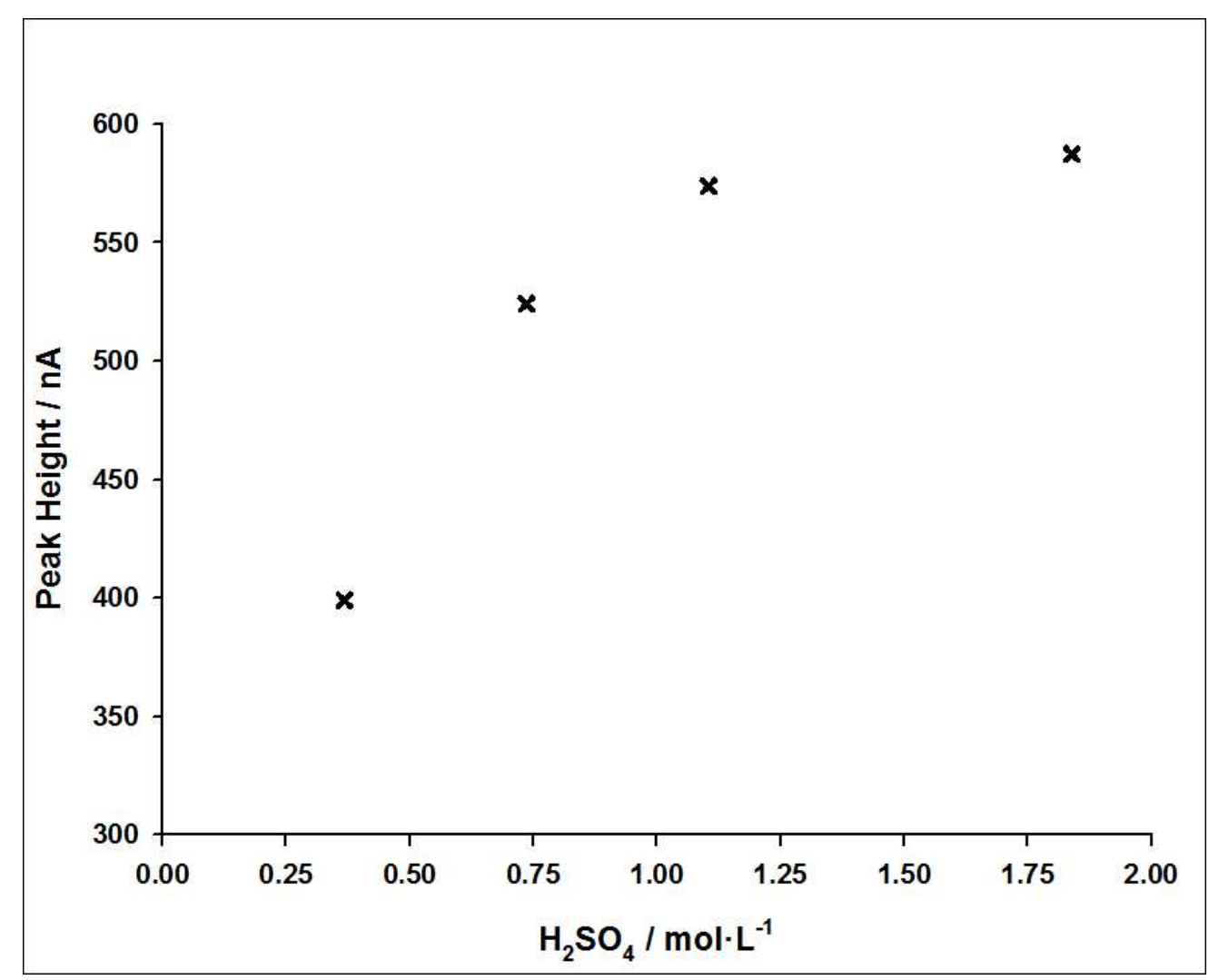

$149 \times 121 \mathrm{~mm}(150 \times 150 \mathrm{DPI})$

http://mc.manuscriptcentral.com/tfac Email: fac@tandf.co.uk 


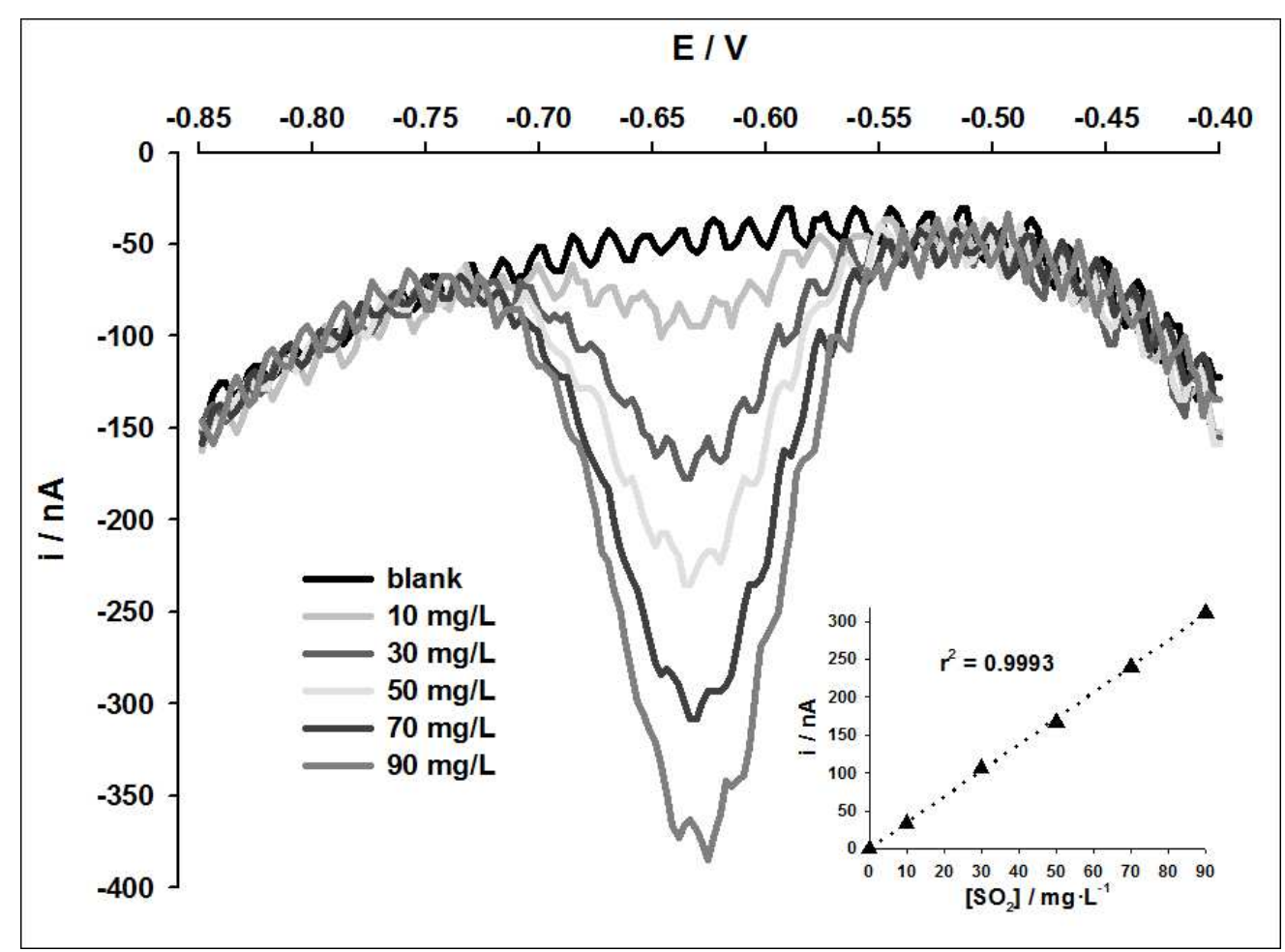

$154 \times 113 \mathrm{~mm}(150 \times 150 \mathrm{DPI})$ 


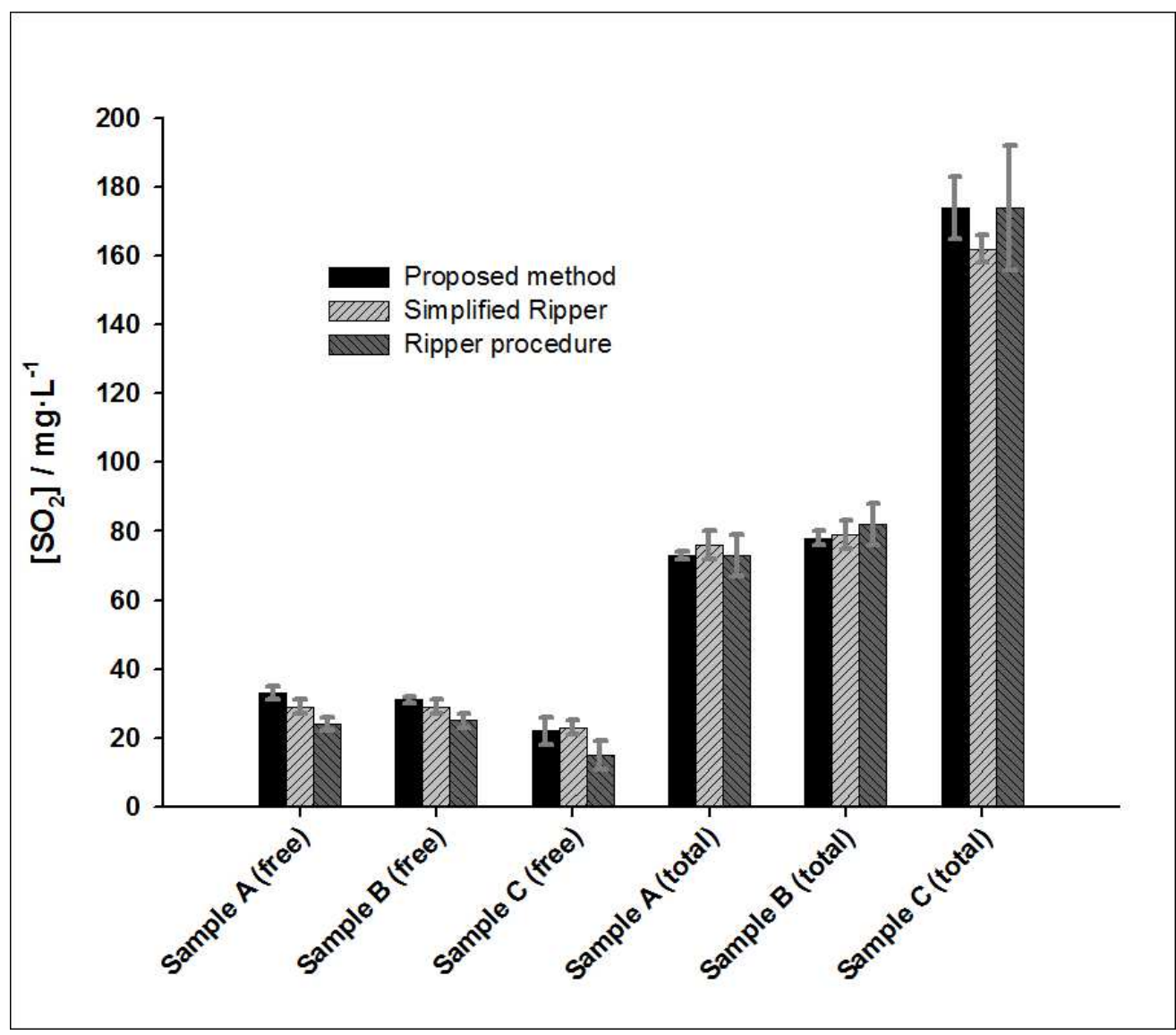

$152 \times 132 \mathrm{~mm}(150 \times 150 \mathrm{DPI})$ 
1

2

3

4

5

6

7

8

9

10

11

12

13

14

15

16

17

18

19

20

21

22

23

24

25

26

27

28

29

30

31

32

33

34

35

36

37

38

39

40

41

42

43

44

45

46

47

48

49

50

51

52

53

54

55

56

57

58

59

60

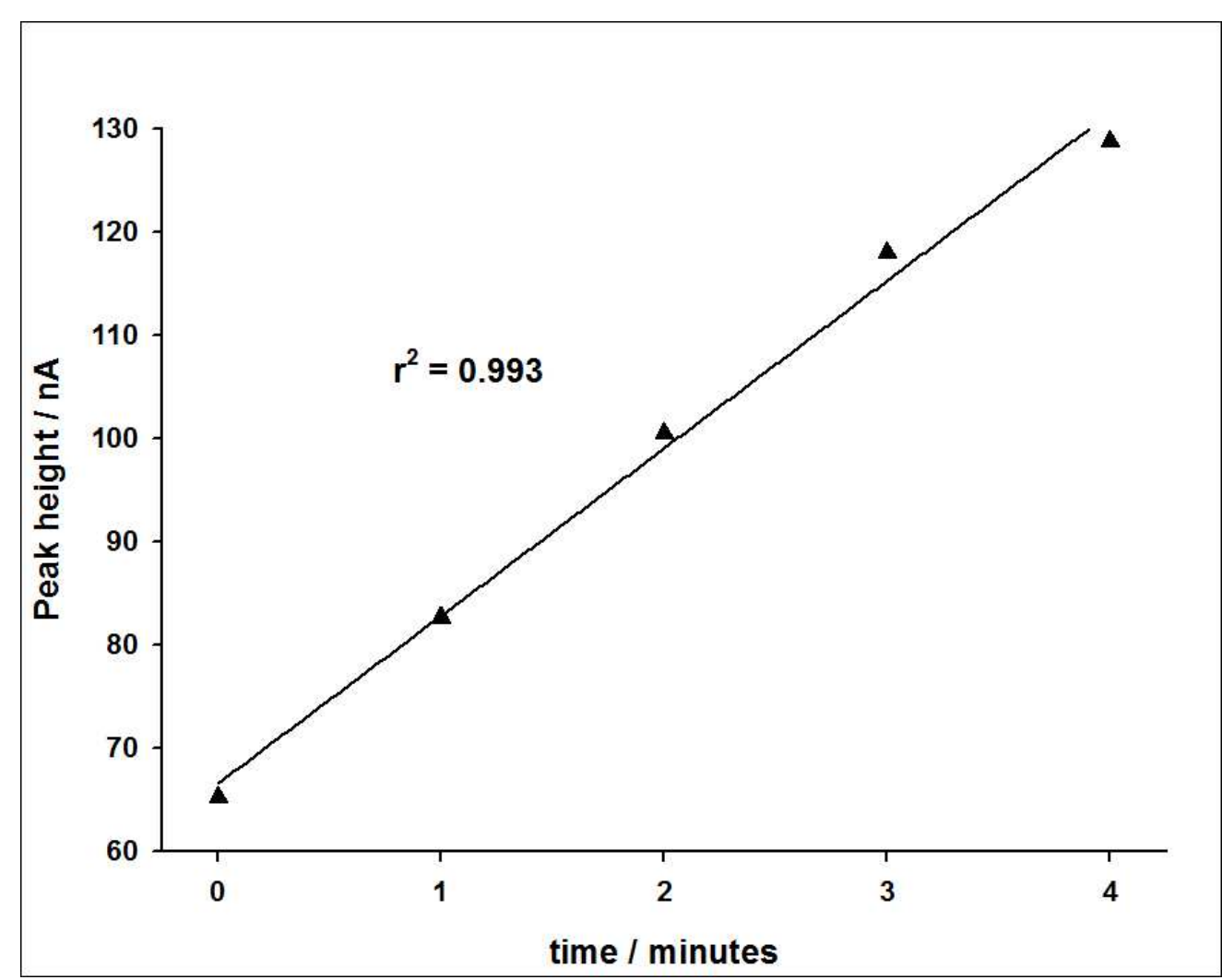

$149 \times 119 m m(150 \times 150$ DPI $)$ 